\title{
Multimodal Analysis of Estimated and Observed Social Competence in Preschoolers With/Without Behavior Problems ${ }^{1}$
}

\author{
Talita Pereira Dias ${ }^{2}$ \\ Maria Stella Coutinho de Alcântara Gil \\ Zilda Aparecida Pereira Del Prette \\ Universidade Federal de São Carlos, São Carlos-SP, Brazil
}

\begin{abstract}
Social skills compete with behavior problems, and the combination of these aspects may cause differences in social competence. This study was aimed at assessing the differences and similarities in the social competence of 26 preschoolers resulting from: (1) groups which they belonged to, being one with social skills and three with behavior problems (internalizing, externalizing and mixed); (2) types of assessment, considering the estimates of mothers and teachers, as well as direct observation in a structured situation; (3) structured situations as demands for five categories of social skills. Children's performance in each situation was assessed by judges and estimated by mothers and teachers. There was a similarity in the social competence estimated by mothers, teachers and in the performance observed. Only the teachers distinguished the groups (higher social competence in the group with social skills and lower in the internalizing and mixed groups). Assertiveness demands differentiated the groups. The methodological aspects were discussed, as well as the clinical and educational potential of the structured situations to promote social skills.
\end{abstract}

Keywords: social skills, behavioral disorders, estimate, observation methods, preschoolers

\section{Análise Multimodal da Competência Social Estimada e Observada de Pré-Escolares com/sem Comportamentos Problemáticos}

\begin{abstract}
Resumo: Habilidades sociais competem com comportamentos problemáticos, e a combinação destes aspectos pode levar a diferenças na competência social. Este estudo teve como objetivo avaliar diferenças e semelhanças na competência social de 26 pré-escolares em função de: (1) grupos a que pertenciam, sendo um com habilidades sociais e três com comportamentos problemáticos (internalizantes, externalizantes e mistos); (2) tipos de avaliação, considerando-se estimativas de mães e de professoras e observação direta em situação estruturada; e (3) situações estruturadas como demandas para cinco classes de habilidades sociais. O desempenho das crianças em cada situação foi avaliado por juízes e estimado pelas mães e professoras. Verificou-se similaridade na competência social estimada por mães, professoras e no desempenho observado. Somente professoras diferenciaram os grupos (maior competência social para o grupo com habilidades sociais e menor para os grupos internalizantes e mistos). Demandas de assertividade diferenciaram os grupos. Foram discutidas as questões metodológicas e o potencial clínico-educacional das situações estruturadas para promoção de habilidades sociais.
\end{abstract}

Palavras-chave: habilidades sociais, distúrbios do comportamento, estimativa, métodos de observação, pré-escolares

\section{Análisis Multimodal de Competencia Social Estimada y Observada en Preescolares con/sin Problemas de Conducta}

\begin{abstract}
Resumen: Habilidades sociales compiten con problemas de conducta, y la combinación de estos aspectos puede dar lugar a diferencias en la competencia social. Este estudio evaluó similitudes y diferencias en la competencia social de 26 preescolares en función de: (1) grupos a que pertenecían, siendo uno con habilidades sociales y tres con problemas de conducta (internalizantes, externalizantes y mixtos), (2) tipos de evaluación, considerándose estimaciones de madres y profesoras y observación directa en situaciones estructuradas; y (3) situaciones estructuradas como demandas para cinco clases de habilidades sociales. El desempeño de los niños fue evaluado por jueces y estimado por las madres y profesoras. Se encontró similitud en la competencia social estimada por madres, profesoras y en el desempeño observado; solamente profesoras diferenciaron los grupos (mayor competencia social para el grupo con habilidades sociales y menor para los grupos internalizantes y mixtos). Demandas de asertividad diferenciaron los grupos. Fueron discutidas cuestiones metodológicas y el potencial clínico y educacional de situaciones estructuradas para promover habilidades sociales.
\end{abstract}

Palabras clave: habilidades sociales, trastornos de la conducta, estimativa, métodos de observación, pre escolares

\footnotetext{
1 Support: São Paulo Research Foundation (FAPESP) and Coordination for the Improvement of Higher Education Personnel (CAPES)

2 Correspondence address:

Talita Pereira Dias. Programa de Pós-Graduação em Psicologia da Universidade Federal de São Carlos. Rodovia Washington Luís, km 235. Bairro Monjolinho. CEP 13565-905. São Carlos-SP, Brazil. E-mail: talitapsi10@yahoo.com.br
}

In the early contexts of socialization, in relation to family or school, parents and teachers value appropriate behaviors for the environment, while seeking to reduce behaviors considered inappropriate or socially undesired, promoting a system of values and rules that is compatible with the culture and social group they belong to (Del Prette \& Del Prette, 2005). The interaction between educational practices and the 
behaviors children present can, however, involve inappropriate conditions for acquiring values and rules. These can lead to the occurrence of both deficits and behavioral excess, which constitute behavior problems (Del Prette \& Del Prette, 2005).

In early childhood, behavior problems can lead to a course of psychosocial risk in later stages of development, with consequences for the children, their families and society (Kerr, Lunkenheimer, \& Olson, 2007; Pacheco \& Hutz, 2009). Some of the damages predominantly caused to children in the short, medium and long terms, suggested by various authors, are: rejection or negligence from peers and significant adults (Walker \& Severson, 2002); academic failure (Crews et al., 2007; Del Prette \& Del Prette, 2005; Walker \& Severson, 2002); psychological disorders, such as social phobia and depressions (Del Prette \& Del Prette, 2005; Morris, Shah, \& Morris, 2002); criminal behavior and involvement with drugs and antisocial groups (Crews et al., 2007; Walker \& Severson, 2002).

Behavior problems can be approached from different perspectives. From the child psychopathology point of view, they were originally classified by Achenbach during the 1960s, into two broader groups: internalizing and externalizing (Achenbach \& Edelbrock, 1978). Crews et al. (2007) define externalizing behavior problems as a response style which is expressed in relation to other people and things and which is more associated to aggression, defiance, argumentation, impulsivity and disobedience; in contrast, internalizing problems constitute a response style which is mainly expressed in relation to the own individual, as a behavioral pattern of social isolation, loneliness, shyness, depression, anxiety and social phobia.

The approach that highlights risk and protection factors associated with behavior problems constitutes a line of research that characterizes the vulnerability or resilience of individuals based on these interaction factors. Among the protection factors, social competence and its related aspects have been emphasized, such as positive interactions, positive sociometric status, pro-social behaviors, empathy and problem solving, which are inter-related aspects addressed in the Social Skills field (Del Prette \& Del Prette, 2005).

Research in the Social Skills field has shown that having a developed set of social skills during childhood entails very positive future implications for individual development. Del Prette and Del Prette (2005) point out evidence that social skills are directly associated with good academic performance, responsible behavior, independence, cooperation, positive self-esteem and with other behavioral patterns that contribute to reinforcing and productive future interpersonal relationships. In contrast, social skills deficits tend to have a negative impact on development, strongly associated with behavior problems that, throughout development, become more stable from pre-adolescence (Del Prette \& Del Prette, 2005). In this context, investing in the assessment and promotion of social competence, from early childhood, can be more effective and bring significant benefits to the healthy development of children.
Social skills and social competence are keywords in the Social Skills field. According to the concepts of Del Prette \& Del Prette (2010), social skills are social behaviors that contribute to social competence and compete with behavior problems that, in turn, compromise social competence. Social competence is the assessment of the performance effectively presented with regard to the articulation of thoughts, feelings and behaviors, as well as to the produced outcome, with functionality criteria related to personal, situational and cultural demands that include instrumental (immediate consequences to the individual, such as the achievement of goals, social approval and positive emotional correlation) and ethical-moral categories (relevant consequences to the individual and social group, such as the maintenance and quality of the relationship, balanced reinforcers, respect and expansion of interpersonal human rights). These authors alert that the assessment of social competence may, therefore, vary from non-efficient performances - generally associated with behavior problems - to highly efficient performances - generally associated with an appropriate set of social skills and with the highest match to the criteria previously mentioned in a given interaction.

Given the diversity of associated criteria, the assessment of social competence is more precise when multiple informants, procedures and instruments are used, which characterize a multimodal approach (Achenbach \& Edelbrock, 1978; Barreto, Freitas, \& Del Prette, 2011; Del Prette \& Del Prette, 2006, 2009). This type of design is important for planning interventions that consider, besides the needs and resources of each specific population, the assessment criteria of educational agents, such as parents and teachers.

Despite being recommended, multimodal assessment has been rarely found in the various studies related to the area. In Brazil, assessments are often based on different informants, but not complemented by direct observation, which is the most appropriate method to assess social competence in relation to its functionality (Del Prette \& Del Prette, 2006). Even indirect methods, through reports involving small children, have been rare in Brazil and abroad, being that the few available studies generally adopt instruments answered by sources like parents and teachers. Studies involving different informants show that mothers and teachers have described the set of children assessed differently. In Bolsoni-Silva, Marturano and Manfrinato (2005), in cases of children with school notifications of behavior problems or socially desired behavior, the assessment of mothers did not distinguish these two groups concerning socially desired behavior, but only in relation to behavior problems. In another data analysis comparing informants, Bolsoni-Silva, Marturano, Pereira and Manfrinato (2006) identified that teachers attributed more behavior problems and less social skills than the children's mothers. The studies exclusively used informants' statements, without assessing the direct performance of the children. The use of only one method of assessment, mainly when it relates to informants' statements, may not be 
sufficient to cover the complexity of possible inter-relations between social skills and behavior problems.

This discrepancy shows the importance of multimodal assessments and, in particular, of including direct observation to add information. Direct observation is also essential in the development of performance indicators (verbal, nonverbal and paralinguistic behaviors) and information about the immediate contingencies that permit showing the criteria of social competence (Del Prette \& Del Prette, 2006). However, direct observation difficulties in natural situations may be one of the reasons why observational studies have also been rare. An alternative for direct observation in natural situations is the use of structured situations that allow access to data about key behaviors by structuring interactive activities that establish requirements for the performance of these behaviors (Del Prette \& Del Prette, 2009).

Taking into consideration that social skills and behavior problems notoriously constitute competing behaviors (Elliott, Gresham, Frank, \& Beddow, 2008; Gresham, 2009), it can be expected that different combinations of these two sets lead to different outcomes concerning social competence. These outcomes could be empirically verified through a performance test, involving children with different sets of social skills and behavior problems, which can be done in structured situations with requirements for different social skills, and registration by direct observation.

The present study focuses on predictive possibilities of different combinations between behavior problems and social skills and is justified by the importance of early assessments of social skills and behavior problems, respectively, as factors of protection and risk for social competence and healthy development. This study is specifically aimed at assessing the differences and similarities in the social competence of preschoolers in function of: (1) groups which they belonged to, being one with social skills and three with behavior problems (internalizing, externalizing and mixed); (2) types of assessment, considering the estimates of mothers and teachers, as well as direct observation in a structured situation; (3) structured situations as demands for five categories of social skills.

\section{Method}

\section{Participants}

Twenty-six children aged between four and six, selected from a sample of 152, participated in this study, and were assessed by mothers and teachers through the Preschool and Kindergarten Behavior Scale (PKBS-BR, Merrell, 2002). The instrument is composed of two scales that assess social skills (34 items) and behavior problems (42 items) and is currently going through a validation process in Brazil by Dias, Freitas, Del Prette \& Del Prette (2011), with satisfactory preliminary psychometric qualities.

The selection was based on criteria for the formation of groups with different combinations of social skills scores and behavior problems: (a) seven children with a set of social skills (CHS) - high scores on the social skills scale and low on both of the behavior problem subscales; (b) seven with internalizing behavior problems (CPI) - high scores on the internalizing behavior problem subscale and low on the social skills scale and on the externalizing behavior problem subscale; (c) four children with externalizing behavior problems (CPE) - high scores on the externalizing behavior problem subscale and low on the social skills scale and on the internalizing behavior problem subscale; and (d) eight children with mixed behavior problems (CPM) - high scores on the internalizing and externalizing behavior problem subscale and low on the social skills scale.

Given that the instrument used did not yet have cut off points, the criteria to define high (above 80 ) or low scores (below 50) were based on the percentile position of the children in the sample. In addition to the 26 children, six others (four girls and two boys), between five and six years old, participated in the study as assistants in the composition of structured situations involving interaction among the children.

In addition, 22 mothers (one of them with two children participating in the study), three grandmothers and 14 teachers, all female, participated as informants. The age of the mothers ranged between 24 and $43(A=32.42$; $S D=4.9)$, and the three grandmothers (which will be referred to as "mothers") were between 40 and 55 years old. The socioeconomic level, measured through the Brazilian Economic Classification Criterion (Brazilian Association of Research Companies [ABEP], 2003), of the mothers/guardians varied from $\mathrm{B} 1$ to $\mathrm{D}$, and most of them were concentrated in classes $C$ and $D$. The age of the teachers ranged from 27 to 46 $(A=34.64 ; S D=6.16)$, and the socioeconomic level ranged from $\mathrm{A} 2$ to $\mathrm{C}$, with half of the teachers belonging to class $\mathrm{B} 2$. The time of teaching was mainly between six and ten years.

Data collection using the PKBS-BR was undertaken in the school where the children studied. The exposure of the children to structured situations and the interviews with the informants were carried out at a private Psychology clinic.

\section{Instruments}

For recording and storing the information handled during data analysis, a recording camera, mini DV tapes, a microcomputer, DVDs, a recorder and headphones were used. In conducting the structured situations, play materials were used, such as toys, objects and gifts for children. The instruments used were the following:

1. Interview Guide for Mothers and Teachers: aimed at standardizing the interviews, a guide with descriptions of the questions the researcher would ask to the teachers and mothers was developed, addressing the manner in which the children assessed would have behaved in different situations (for example: "So, what do you think that [name of the child] did in this situation?"). If the manner in which the children would have behaved was not specified, it was asked: "How do you think they would do this? What did they say or do?” 
2. List of Options of Children's Social Performance for Informants: set of descriptions of social behaviors extracted from the category system adopted in the analysis of recordings. The researcher made the list available to the informants during the interviews, so that they could chose one of the options of social performance. For example, in the situation "Asks for the help of adults when needed", five performance options were presented: "Explicitly asks for help"; "Implicitly asks for help"; "Implicitly asks for help with delay"; "Makes independent attempts"; "Makes independent and incompatible attempts".

3. Description of Audio Recorded Structured Situations: CV with audio descriptions of each structured situation in the study, which the researcher presented to the informants (mothers and teachers), aimed at ensuring a standardized access to the description of each situation.

4. Guide of Structured Situations: written text containing a detailed description of the context of situations, the informants, statements and requirements that were proposed to the children in each of the five structured situations extracted from the PKBS-BR, which the researcher used during the structured situations as a way to ensure the standardization of the statements and actions. The selection of the situations considered the higher frequency of occurrence of the PKBS-BR, in accordance with the assessment of parents and teachers. The social skills converted to structured situations were: "Asking for the help of adults when needed" (the adult handles the wrong key to open the lock that is in the box with the necessary materials for the activity); "Following the instructions of adults" (the adult says they will have to go out and asks the child to hand over the pencils and pens to the classmate who is about to arrive); "Sharing toys and belongings" (the classmate asks the child to borrow a stamp which they do not have); "Standing for their own rights" (in a running situation, the child wins, and the assisting child lies saying that they won) and "Inviting other children to play" (the child is playing with a toy and a classmate arrives).

5. Category System for Assessment of the Children's Social Performance: written text with a set of definitions of possible/predictable behaviors the children may present in the structured situations or the informants may mention in the interviews. The judges consulted this system for the analysis of data obtained from observations and interviews.

6. Protocol for Recording Children's Social Performance: form with space for the judges of the study to record the option of behavior the children presented in relation to each situation, based on the analysis of the recordings, with the purpose of assisting with organization and analysis of data.

7. Protocol for Recording the Informants' Statements in relation to Children's Social Performance: form with accurate transcription of the answers provided by the informants to the open and close questions, in addition to space for the judges to categorize these answers, based on the options available in the Category System for Assessment of the Children's Social Performance. The purpose was to assist with the organization and analysis of data provided by the informants.

\section{Procedure}

Data collection. Mothers and teachers were contacted at the schools where the children used to study and their agreement to participate in the study was requested. After agreeing to participate in the research, a period of adaptation between the researcher and children in the schools was carried out during the break and in the classroom, lasting approximately 20 hours, followed by the beginning of data collection with the children, undertaken at the Psychology clinic after school hours.

For direct observation of children's performance in structured situations, which took place at the Psychology clinic, children remained for a period of time in the waiting room, and then the researcher invited them to play in another room, with other toys, taking them to the room where the structured situations were held. Each child was exposed to five structured situations, adopting the Guide of Structured Situations. The situations were organized into two sessions (three situations in one session and two in another), which took place on different days in order to avoid fatigue. Each of the sessions was fully videotaped for subsequent analysis of the performances. During the structured situations, the child interacted with the assisting child or with the researcher in play situations, without knowing that they were being evaluated.

After data collection with the children, mothers and teachers were individually interviewed by the researcher, based on the Interview Guide for Mothers and Teachers, adopting the audio CD with the description of the situations. When the informants were asked what the children would have done in a certain situation, they were required to provide specific details (vocal and motor behavior). Afterwards, the list of options of children's social performance for informants was presented, asking the informants interviewed to select the option that best represented their estimate about the possible behavior of the children and to justify their choice of such option. All interviews were audio recorded.

Data analysis. Two independent judges were trained until they reached an $85 \%$ agreement rate when compared with the performance of the researcher. Each of the judges watched the recordings and individually evaluated the registrations filmed in relation to half of the children studied, and also completed the Protocol for Recording Children's Social Performance with the categories related to the behavior presented by the children. The judges classified the statements of the sources by completing the Protocol for Recording Informants' Statements about Children's Social Performance. The categories the judges registered were converted into a numerical scale that represented the level of social competence associated with each category, which ranged from -4 (Maximum negative extreme $=$ totally impairs social competence) to +4 
(Maximum positive extreme $=$ totally contributes to social competence). The scores permitted calculating the average score of social competence and the performance of statistical analyses to compare the groups in the same assessment (Kruskal-Wallis for independent samples) and the three assessments for each group (Friedman test for related samples). Taking into consideration the reduced sample size, a visual descriptive analysis of the patterns was developed. SPSS version 15.0 and BioEstat version 3.0 statistical software was used.

\section{Ethical Considerations}

The study received approval from the Ethics Committee of the Universidade Federal de São Carlos (Process 330/2008), in compliance with Resolution CNS 196/96 on research involving human beings.

\section{Results}

Figure 1 presents the average social competence scores as estimated by mothers and teachers, as well as through the direct observation of each child, for each of the groups (CHS, CPI, CPE and CPM). Non-parametrical inferential analysis (Kruskal-Wallis test for independent samples) revealed no significant differences in the mothers' estimates $(p=.11)$. However, through descriptive analysis and visual inspection of Figure 1, it was observed that group CHS had consistently higher scores in the three assessments, and that group CPI presented higher variability with average scores ranging from -0.80 to 3.52. The medians of groups CHS and CPE (respectively 3.18 and 3.16) were close to the highest possible score (4), while the medians of groups CPI and CPM (1.56 and 1.84) were below 2 . The group CPE showed that the children obtained more homogenous scores (2.52 to 3.53).

$$
\square \begin{aligned}
& \text { Average } \\
& \text { score mothers }
\end{aligned} \quad \begin{aligned}
& \text { Average } \\
& \text { score teachers }
\end{aligned} \square \begin{aligned}
& \text { Average score } \\
& \text { observation }
\end{aligned}
$$

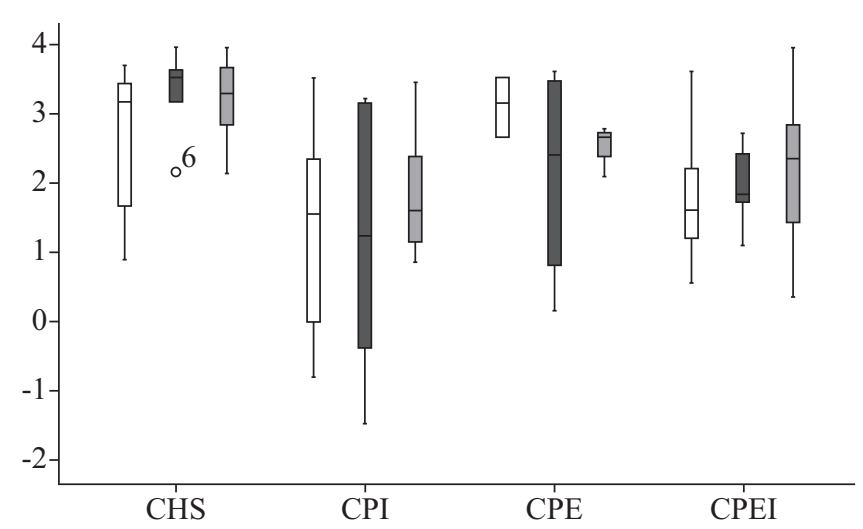

Figure 1. Social Competence Scores Based on the Estimate Provided by Mothers and Teachers and on the Direct Observation of Children's Performance in the Groups with a Set of Social Skills (CHS), Internalizing Behavior Problems (CPI), Externalizing Behavior Problems (CPE) and Mixed Behavior Problems (CPM).
The non-parametric Kruskal-Wallis test showed differences among the groups ( $p=.025)$ in the estimates of the teachers, with significantly higher social competence scores in group CHS $(M-20.71)$ than in groups CPM (10.5) and CPI $(M=$ 9.57). Children in group CHS received a strongly positive assessment in relation to the other groups $(M d=3.52)$. The low variability of average scores and the presence of a lower atypical value (Child 6) are also highlighted in group CHS. Similarly to the mothers' assessment, the median (1.24) of the teachers' estimates for group CPI was close to the lowest possible scores and presented higher variability (score from 1.48 to 3.22), while CPM showed lower variability $(S D=0.55)$.

In the observational assessment of structured situations, the non-parametric (Kruskal-Wallis) statistical analysis did not show significant differences $(p=.083)$ among the groups. The descriptive analysis showed a median closer to the maximum score for CHS (3.30) and to the minimum score for group CPI (1.60), with higher variability in the latter (scores between 2.14 and 3.96), which is consistent with other assessments. In relation to CPM, higher variability concerning social competence can also be seen, contrary to what occurred in group CPE $(S D=0.31)$.

In intergroup comparisons, among different types of assessment, Friedman's inferential analysis for related samples did not show significant differences in the three assessments (mothers, teachers and observation of structured situations) performed for groups CHS ( $p=.87)$, CPI $(p=.37)$, CPE $(p=.78)$ and CPM $(p=.67)$. As for the descriptive analysis, it can be noted that group CHS had medians very close to the maximum scores, both in the assessment of mothers and teachers and in the observation. In the teachers' assessment, more than $50 \%$ of the children in this group had scores above 3.53. The mothers' assessment, however, showed high dispersion between the scores below the median, indicating greater inconsistency in relation to the data. In relation to group CPI, the average scores of more than $50 \%$ of the group were above 1.60 and, in the observation data, with the assessment of teachers and mothers, had medians from 1.24 to 1.56 respectively. In group CPE, scores closer to the maximum were obtained in the mothers' assessment, followed by direct observation, with high dispersion in the teachers' evaluation $(S D=1.63)$ and low dispersion in the assessment by observation $(S D=0.31)$. Finally, in group CPM, the assessment by observation presented quite varied scores, with an intermediate median in the possible extent of the social competence scores.

In the analysis of the social competence scores for each of the five structured situations, the average and standard deviations of the social competence for each, considering each assessor and sample or group, are seen in Figure 2. It can be observed that situation 2 "Following the instructions of adults", presented medians closer to the maximum score for the three types of assessment, followed by situation 5 "Inviting other children to play”, except in group CPI. In contrast, situation 3 "Standing for their own rights" presented the lowest scores, also with negative scores for the informants’ assessment. 


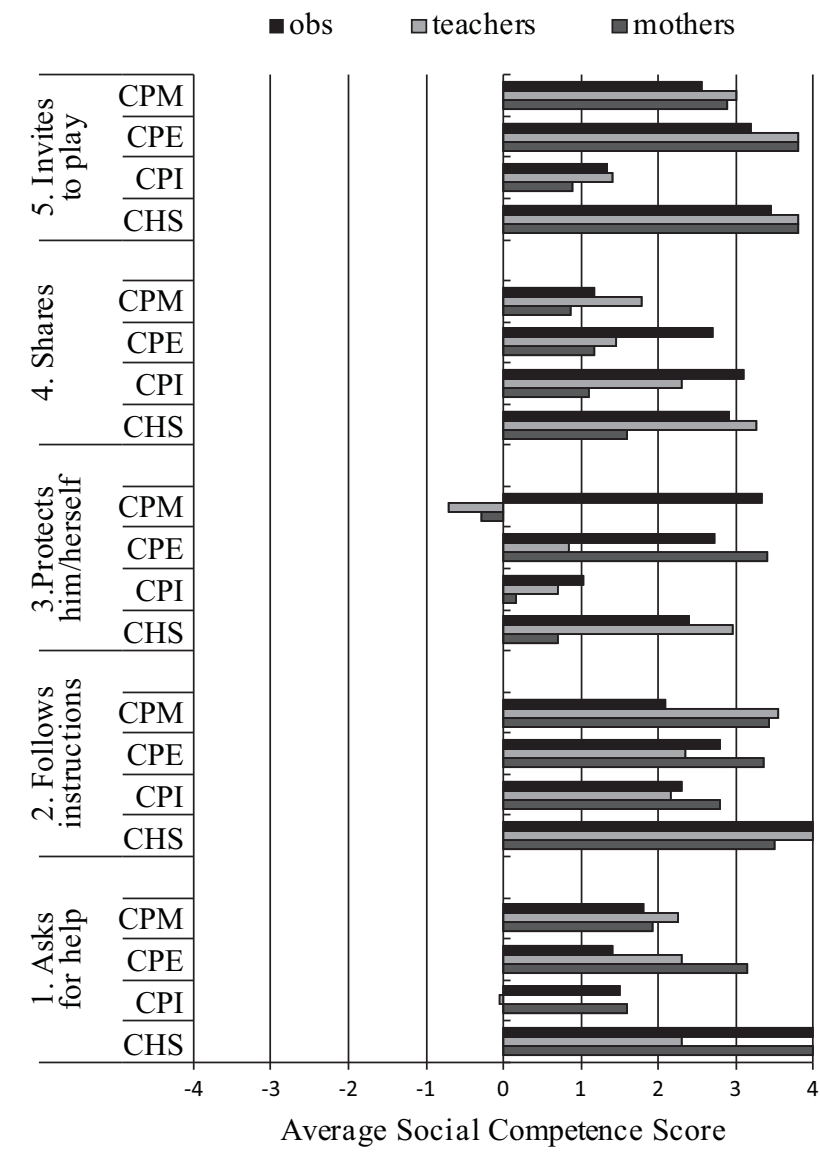

Figure 2. Average Scores of Social Competence Obtained by the Children from the Groups with a Set of Social Skills (CHS), Internalizing Behavior Problems (CPI), Externalizing Behavior Problems (CPE) and Mixed Behavior Problems (CPM), in the Assessment of the Mothers, Teachers and by Direct Observation of the Performance in relation to each Structured Situation.

In all the assessments and situations, the children in group CHS had medians corresponding to the maximum score for the assessment by observation in all situations, and in four out of five situations for the assessment of teachers. Conversely, the medians of the children in group CPI were generally lower in relation to all situations, except for situation 4 "Sharing toys and belongings", in the assessment of teachers and in the three assessments by observation. In situation 5, "Inviting other children to play", the median scores were low for the three types of assessment. In relation to group CPE, the median scores of the children were closer to the maximum scores in the assessment of the mothers for all situations, except for situation 4 "Sharing toys and belongings”. Concerning group CPM, there was a higher dispersion between the situations and assessments. The median scores of the children in this group were low for situation 4 "Sharing toys and belongings", in the assessment of the teachers and by observation, and in situation 3 "Standing for their own rights", in both assessments of the informants; however, in the assessment by observation, the children in group CPM showed the highest score in relation to this skill.
When comparing the reports of the mothers and the teachers, as well as the observation in structured situations, the most favorable assessment by observation occurred in situations 2 "Following the instructions of adults" and 3 "Standing for their own rights". The assessment of the mothers was particularly more positive in situation 1 "Asking for the help of adults when needed", and of the teachers in situation 4 "Sharing toys and belongings". Higher consistency between the assessors and observation data was seen in situation 5 "Inviting other children to play", between the assessment of the teachers and observation in situation 4 "Sharing toys and belongings", and between the informants in situation 2 "Following the instructions of adults".

\section{Discussion}

In a multimodal assessment that considered the estimates of mothers and teachers, as well as the direct observation of children in structured situations, the results showed more similarities than differences among the groups with distinctive combinations of social skills and behavior problems. The groups CHS, CPI, CPE and CPM were similarly assessed concerning the social competence scores, according to the reports of mothers, teachers and the observation of performance.

The results about the estimates of mothers are consistent with the findings of the study developed by Bolsoni-Silva et al. (2005), in which the assessment of desirable behaviors by the mothers of children with behavior problems was not different from the assessment of the mothers of children with social skills. On the other hand, the fact that the estimates of the informants and the observation data showed similar results for all groups partially contradicts the assumption of the study that mothers and teachers would tend to underestimate the social competence of children with behavior problems. The convergence in the assessment data can be due to the use, in structured situations, of the social skills the mothers and teachers considered more frequent and more important. As a consequence, it can be concluded that the informants would be more attentive to these behaviors, showing more accurate reports when assessing these behaviors.

When the two types of assessment were compared, through the reports of mothers and teachers, differences were not found for the groups, as opposed to the findings of Bolsoni-Silva et al. (2006). The discrepancy may be related to the procedures adopted: in the study of Bolsoni-Silva et al., the instrument used was a questionnaire with items of social skills while, in the present study, the interviews produced scores of the children's social competence. The two procedures can, therefore, have assessed different constructs: social skills in the first and social competence in the second.

As for the assessment by observation, the groups were not significantly distinguished in relation to the social competence score, which is contrary to the initial assumption of the present study that behavior problems, when competing with social skills (Elliott et al., 2008), would involve different levels of social competence assessed through structured 
situations. Under this assumption, it was expected that, in structured situations, the children in the socially skilled group would have a better performance than those in the behavior problems group. The results obtained in the present study would be more in line with other studies that question the assumption of competition between behavior problems and social skills (Farmer \& Xie, 2007).

Specifically focusing on some of the subtypes of aggression, Estell, Cairns, Farmer and Cairns (2002) found that these problems did not affect the popularity and acceptance of the children in relation to their peers. Taking into consideration the variables assessed in these studies and in the present study, the results obtained suggest some explanations or alternative assumptions to examine the issue related to the relationship between social skills and behavior problems.

One possible explanation is that, when organizing the previous condition for the occurrence of specific social behaviors in a structured situation, a stronger contextual control is established over children's behavior, which favors more similarities among the groups despite the previous differences in the skills set. This assumption rests on the understanding that children with behavior problems have deficits in relation to performance or fluency, but not to acquisition (Del Prette \& Del Prette, 2005), that is, they have the skills but may or may not perform them depending on the contextual control. Another possibility can be the fact that, at this age, children have not yet consolidated the behaviors that are indicative of social competence and/or behavior problems that are still initiating in their skills set, particularly in relation to new environments, in which stability has been predicted from pre-adolescence (Loeber, 1991).

This alternative explanation for the results obtained in the present study suggests an unexpected function of structured situations, not restricted to the assessment: their potential to evoke expected/desirable social behaviors in preschool children, regardless of their usual skills set. This possibility suggests the importance of planning and implementing favorable conditions for the expression, strengthening and improvement of different categories of social skills for children with behavior problems. It also supports the creation of particularly feasible procedures in early interventions involving children with behavior problems, because the social skills deficits would not be generalized for different contexts (Gresham, Lane, MacMillan, \& Bocian, 1999). In that sense, the structured situations could be explored as an intervention resource for the promotion of desirable behaviors. Under the conditions established by the structured situation, the expected behaviors could be more easily molded and improved towards complex and proficient social skills, and/or strengthened through differential reinforcement. This procedure presents similarities to the one used in a study by Moura and Venturelli (2004), in relation to the proposal to conduct a therapeutic process with children from seven to 12 years of age, and mentions the training sessions of specific skills, in which behaviors that replace behavior problems are trained with the children. This training is similar to the procedure of structured situations used in the present study, which was shown to be effective for smaller children from four to six years of age presenting behavior problem indicators.

In summary, the present study brings additional factors about the complexity of the relationship between social skills and behavior problems, which continues to be an important question for research. However, the possibility that the small sample size and the percentile position criteria for the formation of the groups (instead of using cut off points, not yet available for the used instrument) have affected the results cannot be ruled out, which also suggests the development of further studies, especially with larger samples, besides new studies of the instrument's discriminant validity.

The analysis of the different structured situations for direct observation suggests that the skills "Following the instructions of adults" and "Inviting other children to play" would be more frequent and improved in preschool children, certainly because they tend to be positive and consistently sequenced in play situations. But the ability of "Standing for their own rights", related to assertiveness, although still initiating in most of the children participating in the study, was more developed in children from group CPM (observation data, not from reports), and suggested that the informants did not identify and, therefore, could not have sequenced this behavior so consistently and positively. One consequence of this finding for clinical and educational Social Skills interventions is the need to previously inform parents and teachers about the importance of assertiveness in the development of children's social skills and demystify the negative assessment generally associated with such types of behavior (Dias, Freitas, Souza, Del Prette, \& Del Prette, 2008).

\section{Conclusions}

This study reiterates the importance of multimodal assessments in the Social Skills field with methodological, educational and clinical consequences, suggesting the need for further investigations. A methodological consequence was the consistency among the three types of assessment for each group, suggesting reliability of the assessments, which shows validity and complementarity between the report strategies (interviews) and observation in structured situations involving preschool children.

Some limitations of this study can be identified, such as the small sample size and disregard of the variables gender, age and socioeconomic status. Based on the contributions and limitations mentioned above, further research can be undertaken with larger samples, with preschool children, and aimed at identifying situations most likely to distinguish the social competence of children from different groups. It would also be important to develop studies with the same procedures, but using samples matching the relevant sociodemographic variables suggested by the literature as potentially associated with the relationship between social competence and behavior problems. 


\section{References}

Associação Brasileira de Empresas de Pesquisa. (2003). Critério de Classificação Econômica Brasil. Recuperado 18 abril 2007, dehttp://www.abep.org/novo/FileGenerate. ashx?id=249

Achenbach, T. M., \& Edelbrock, C. S. (1978). The classification of child psychopathology: A review and analysis of empirical efforts. Psychological Bulletin, 85(6), 1275-1301. doi:10.1037/0033-2909.85.6.1275

Barreto, S. O., Freitas, L. C., \& Del Prette, Z. A. P. (2011). Habilidades sociais na comorbidade entre dificuldades de aprendizagem e problemas de comportamento: Uma avaliação multimodal. Psico, 42(4), 503-510.

Bolsoni-Silva, A. T., Marturano, E. M., \& Manfrinato, J. W. S. (2005). Mães avaliam comportamentos socialmente “desejados" e "indesejados" de préescolares. Psicologia em Estudo, 10(2), 245-252. doi:10.1590/S1413-73722005000200011

Bolsoni-Silva, A. T., Marturano, E. M., Pereira, V. A., \& Manfrinato, J. W. S. (2006). Habilidades sociais e problemas de comportamento de pré-escolares: Comparando avaliações de mães e de professoras. Psicologia: Reflexão e Crítica, 19(3), 460-469. doi:10.1590/S0102-79722006000300015

Crews, S. D., Bender, H., Cook, C. R., Gresham, F. M., Kern, L., \& Vanderwood, M. (2007). Risk and protective factors of emotional and/or behavioral disorders in children and adolescents: A mega-analytic synthesis. Behavioral Disorders, 32(2), 64-77.

Del Prette, Z. A. P., \& Del Prette, A. (2005). Psicologia das habilidades sociais na infância: Teoria e prática. Petrópolis, RJ: Vozes.

Del Prette, Z. A. P., \& Del Prette, A. (2006). Avaliação multimodal de habilidades sociais em crianças: Procedimentos, instrumentos e indicadores. In M. Bandeira, Z. A. P. Del Prette, \& A. Del Prette (Orgs.), Estudos sobre habilidades sociais e relacionamento interpessoal (pp. 47-68). São Paulo: Casa do Psicólogo.

Del Prette, Z. A. P., \& Del Prette, A. (2008). Um sistema de categorias de habilidades sociais educativas. Paidéia (Ribeirão Preto), 18(41), 517-530. doi:10.1590/S0103-863X2008000300008

Del Prette, Z. A. P., \& Del Prette, A. (2009). Avaliação de habilidades sociais: Bases conceituais, instrumentos e procedimentos. In Z. A. P. Del Prette \& A. Del Prette (Orgs.), Psicologia das habilidades sociais: Diversidade teórica e suas implicações (pp. 187-229). Petrópolis, RJ: Vozes.

Del Prette, Z. A. P., \& Del Prette, A. (2010). Habilidades sociais e análise do comportamento: Proximidade histórica e atualidades. Perspectivas em Análise do Comportamento, 1(2), 104-115.
Dias, T. P., Freitas, L. C., Del Prette, Z. A. P., \& Del Prette, A. (2011). Validação da escala de comportamentos sociais de pré-escolares para o Brasil. Psicologia em Estudo, 16(3), 447-457. doi:10.1590/S1413-73722011000300012

Dias, T. P., Freitas, L. C., Souza, T. M. P., Del Prette, A., \& Del Prette, Z. A. P. (2008). Validade social das habilidades sociais sob a perspectiva do professor: Replicação com amostra ampliada. In M. A. Almeida, E. G. Mendes, \& M. C. P. I. Hayashi (Orgs.), Temas em educação especial: Múltiplos olhares (pp. 347-355). Araraquara, SP: Junqueira \& Marin; Brasília, DF: CAPES/PROESP.

Elliott, S. N., Gresham, F. M., Frank, J. L., \& Beddow, P. A., III. (2008). Intervention validity of social behavior rating scales: Features of assessments that link results to treatment plans. Assessment for Effective Intervention, 34(1), 15-24. doi:10.1177/1534508408314111

Estell, D. B., Cairns, R. B., Farmer, T. W., \& Cairns, B. D. (2002). Aggression in inner-city early elementary classrooms: Individual and peer-group configurations. Merrill-Palmer Quarterly, 48(1), 52-76. doi:10.1353/mpq.2002.0002

Farmer, T. W., \& Xie, H. (2007). Aggression and school social dynamics: The good, the bad, and the ordinary. Journal of School Psychology. 45(5), 461-478. doi:10.1016/j.jsp.2007.06.008

Gresham, F. M. (2009). Análise do comportamento aplicada às habilidades sociais. In A. Del Prette \& Z. A. P. Del Prette (Orgs.), Psicologia das habilidades sociais: Diversidade teórica e suas implicações (pp. 17-66). Petrópolis, RJ: Vozes.

Gresham, F. M., Lane, K. L., MacMillan, D. L., \& Bocian, K. M. (1999). Social and academic profiles of externalizing and internalizing groups: Risk factors for emotional and behavioral disorders. Behavioral Disorders, 24(3), 231-245.

Kerr, D. C., Lunkenheimer, E. S., \& Olson, S. L. (2007). Assessment of child problem behaviors by multiple informants: A longitudinal study from preschool to school entry. Journal of Child Psychology and Psychiatry, 48(10), 967-975.

Loeber, R. (1991). Antisocial behavior: More enduring than changeable? Journal of the American Academy of Child \& Adolescent Psychiatry, 30(3), 393-397. doi:10.1097/00004583-199105000-00007

Merrell. K. W. (2002). Preschool and Kindergarten Behavior Scales. $2^{\text {nd }}$ ed. Austin, TX: PRO-ED.

Morris, R. J., Shah, K., \& Morris, Y. P. (2002). Internalizing behavior disorders. In K. L. Lane, F. M. Gresham, \& T. E. O' Shaughnessy (Eds.), Interventions for children with or at risk for emotional and behavioral disorders (pp. 223241). Boston, MA: Allyn \& Bacon.

Moura, C. B., \& Venturelli, M. B. (2004). Direcionamentos para a condução do processo terapêutico comportamental com crianças. Revista Brasileira de Terapia Comportamental e Cognitiva, 6(1), 17-30. 
Pacheco. J. T. B., \& Hutz, C. S. (2009). Variáveis familiares preditoras do comportamento anti-social em adolescentes autores de atos infracionais. Psicologia: Teoria e Pesquisa, 25(2), 213-219. doi:10.1590/S0102-37722009000200009

Walker, H. M., \& Severson, H. H. (2002). Developmental prevention of at-risk outcomes for vulnerable antisocial children and youth. In K. L. Lane, F. M. Gresham, \& T. E. O’ Shaughnessy (Eds.), Interventions for children with or at risk for emotional and behavioral disorders (pp. 177-194). Boston, MA: Allyn \& Bacon.

Talita Pereira Dias is Ph.D. Student in Psychology, Universidade Federal de São Carlos, São Carlos-SP, Brazil.

Maria Stella Coutinho de Alcântara Gil is Associate Professor, Universidade Federal de São Carlos, São Carlos-SP, Brazil.

Zilda Aparecida Pereira Del Prette is Full Professor, Universidade Federal de São Carlos, São Carlos-SP, Brazil.

Received: May $10^{\text {th }} 2012$

$1^{\text {st }}$ Revision: Sep. $26^{\text {th }} 2012$

Approved: Dec. $21^{\text {st }} 2012$

How to cite this article:

Dias, T. P., Gil, M. S. C. A., \& Del Prette, Z. A. P. (2013). Multimodal analysis of estimated and observed social competence in preschoolers with/without behavior problems. Paidéia (Ribeirão Preto), 23(55), 197-205. doi:10.1590/1982-43272355201307 


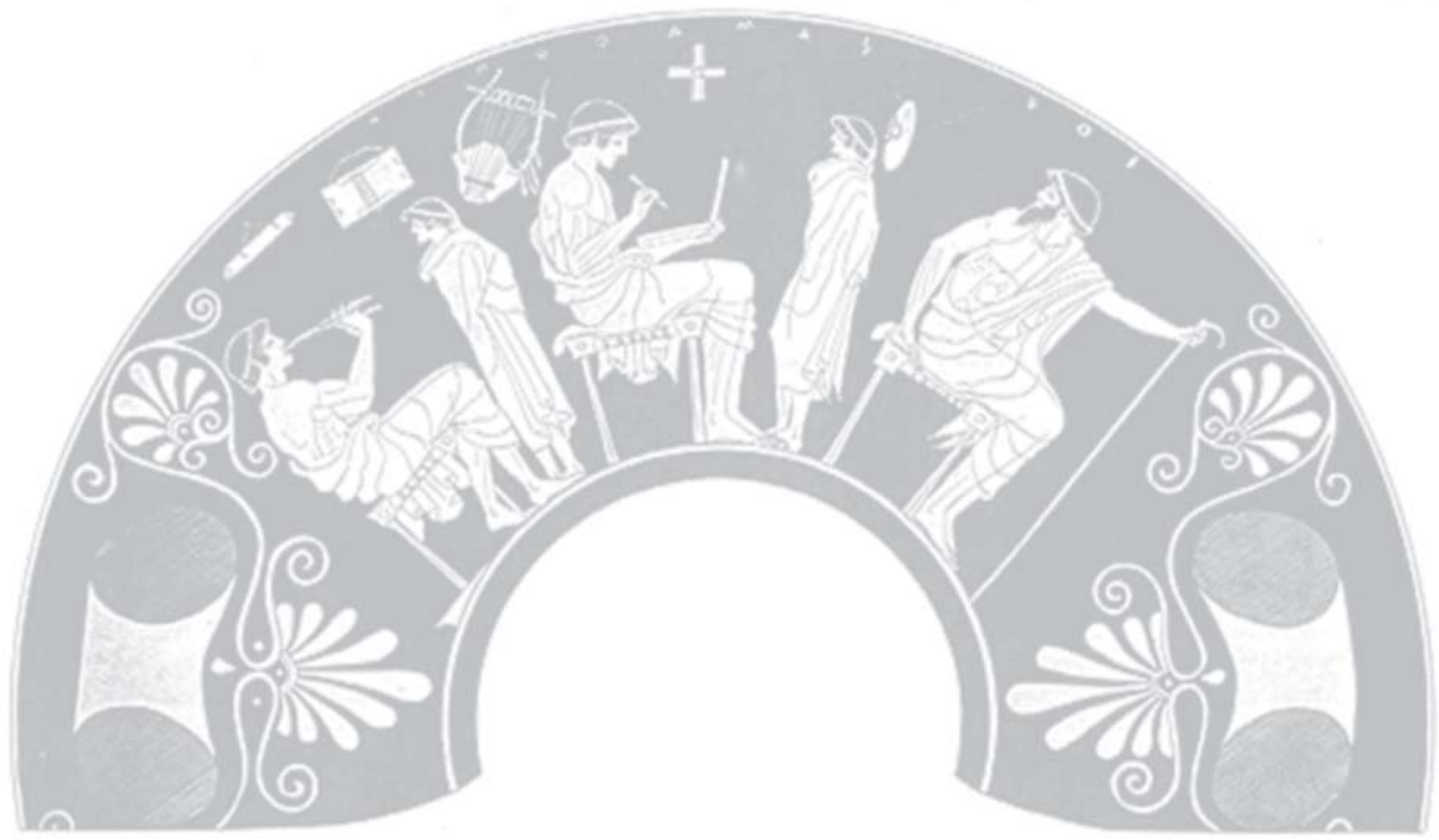

